\section{Development of a New Harvest Container for Wild Blueberries}

\author{
Charles F. Forney ${ }^{1}$, Leonard J. Eaton ${ }^{2}$, and Leigh $\mathrm{GaO}^{3}$
}

ADDITIONAL INDEX WORDs. transport, handling, fruit quality, crushing, lowbush blueberry, Vaccinium angustifolium

SUMMARY. Increasing the size of containers used to transport wild lowbush blueberry (Vaccinium angustifolium) fruit from the field to the processing facility has the potential to increase handling efficiency. Currently the wild blueberry industry uses a standard 18-inch-long $\times 15$-inch-wide $\times 5$-inch-deep plastic container that holds about $20 \mathrm{lb}$ of fruit. This study examined the development of a new, pallet-sized high-capacity blueberry container and determined its effects on fruit quality following harvesting, transport, and processing. Laboratory studies on the effects of packing depth of berries on fruit quality demonstrated that container depths of $\mathbf{1 4 . 2}$ inches were damaging to fruit 24 hours following harvest, transport, and holding under ambient conditions, while depths of 7.1 inches were not. In commercial trials with larger pallet-sized prototype containers, fruit depths of up to 10 inches were not damaging to fruit under otherwise typical commercial handling conditions. Dumping fruit from the 10 -inch-deep pallet-sized containers onto conveyer belts at the processing facility caused minimal damage to the fruit. In addition, fruit crushing that occurred in the large pallet-sized containers was similar to that occurring in the standard 20-1b plastic containers currently used by the industry. Results of these studies indicate that large pallet-size blueberry containers with a depth of 10 inches could be used without causing significant damage to fresh fruit during harvest, transport, and processing. Thus as a whole, the adoption of this type of container would improve handling efficiency and potentially the quality of the fruit.

$\mathrm{T}$ he fruit of wild lowbush blueberries has long been valued for its high flavor and nutritional value. Wild blueberries are native to northeastern North America, including Maine, Quebec, and the Atlantic provinces of Canada. Large native stands of these fruit have been har-

${ }^{1}$ Agriculture and Agri-Food Canada, Atlantic Food and Horticulture Research Centre, 32 Main St., Kentville, N.S., B4N 1J5, Canada.

${ }^{3}$ Nova Scotia Agricultural College, Department of Environmental Sciences, P.O. Box 550, Truro, N.S., B2N 5E3, Canada.

${ }^{4}$ PEI Food Technology Centre, 101 Belvedere Ave., P.O. Box 2000, Charlottetown, PE., ClA 7N8, Canada.

Contribution No. 2280 of the Atlantic Food and Horticulture Research Centre, Agriculture and AgriFood Canada. We thank Bragg Lumber Company Ltd. (Collingwood, N.S., Canada) and Doug Bragg Enterprises Ltd. (Collingwood, N.S., Canada) for financial assistance; Elwood Lawton and the harvesters who loaded and shipped the containers; Oxford Frozen Foods Ltd. (Oxford, N.S., Canada) for their help in fruit sampling; Carolyn Domytrak, Jay Poulain and others for technical assistance in the evaluation of fruit quality; Sherry Fillmore for statistical analysis; and John M. DeLong and Andrew R. Jamieson for their helpful suggestions in preparing the manuscript.

${ }^{1}$ Postharvest Physiologist; corresponding author; email: forneyc@agr.gc.ca

${ }^{2}$ Research Professor

${ }^{3}$ Food Scientist/Engineer. vested over the centuries. Recently, fields have increased production dramatically. Over the last 25 years wild blueberry production has increased an average of 5 million $\mathrm{lb}$ per year and now totals nearly 160 million $\mathrm{lb}$ per annum (Yarborough, 2005). Over $95 \%$ of this fruit is frozen soon after harvest and used to produce various consumer products.

The quality of frozen fruit is dependent on maturity and quality of the fruit at harvest, as well as the effects of harvesting, postharvest handling, and processing. If the incidence of overripe or damaged fruit is high, the amount of unusable fruit removed during proagronomic practices in managed wild

cessing will lower the efficiency of fruit processing and yield of the final frozen product. Fruit must be firm at the time of harvest and must be handled gently and quickly from harvest to processing and freezing. Delays in this process result in increased breakdown, softening, and reduced quality of frozen fruit (Jackson et al., 1999). The period from harvest to processing should be $<20 \mathrm{~h}$ in order to minimize berry softening and loss. When delays are $>24 \mathrm{~h}$, losses in berry firmness can be substantial. In addition, postharvest temperatures of the fruit prior to freezing also affect quality of wild blueberries (Sanford et al., 1991). Holding fruit for prolonged periods at high temperatures results in increased numbers of damaged fruit and loss of firmness.

Efficient harvesting and postharvest handling of fruit is important to maintain fruit quality and ensure financial return to the industry. The industry has evolved over the past century from hand-picking into $\mathrm{l}$-qt-sized boxes, to raking into 20 -lb wooden tubs (Kinsman, 1986), to harvesting into plastic field containers (Kinsman, 1993). Plastic field containers, which are $18 \times$ $15 \times 5$ inches [length $(\mathrm{L}) \times$ width $(\mathrm{W})$ $x$ depth (D)] in size and hold about $20 \mathrm{lb}$ of fruit (Fig. 1), have become the industry standard for handling harvested fruit. These containers are suitable for use with both hand-raking and mechanical harvesting. There has been a trend in recent years to increase the use of mechanical harvesting for wild blueberries in light of acreage increases. Mechanical harvesting of small fruit can increase labor productivity by a factor of 12 to 20 times (Peterson, 1992). Since the development of a successful mechanical harvester for wild blueberries in 1979, the acreage being mechanically harvested has increased steadily and now comprises $77 \%, 52 \%$, $25 \%, 15 \%$, and $5 \%$ of the total acreage

\begin{tabular}{llll}
\hline $\begin{array}{l}\text { Units } \\
\begin{array}{l}\text { To convert U.S. to SI, } \\
\text { multiply by }\end{array}\end{array}$ & U.S. unit & SI unit & $\begin{array}{l}\text { To convert SI to U.S., } \\
\text { multiply by }\end{array}$ \\
\hline 29.5735 & $\mathrm{fl} \mathrm{oz}$ & $\mathrm{mL}$ & 0.0338 \\
0.0283 & $\mathrm{ft}^{3}$ & $\mathrm{~m}^{3}$ & 35.3147 \\
3.7854 & $\mathrm{gal}$ & $\mathrm{L}$ & 0.2642 \\
2.5400 & inch(es $)$ & $\mathrm{cm}$ & 0.3937 \\
25.4000 & inch(es) & $\mathrm{mm}$ & 0.0394 \\
0.4536 & $\mathrm{lb}$ & $\mathrm{kg}$ & 2.2046 \\
4.4482 & $\mathrm{lbf}$ & $\mathrm{N}$ & 0.2248 \\
0.1751 & $\mathrm{lbf} /$ inch & $\mathrm{N} \cdot \mathrm{mm}^{-1}$ & 5.7101 \\
1.6093 & $\mathrm{mile}(\mathrm{s})$ & $\mathrm{km}$ & 0.6214 \\
28.3495 & $\mathrm{Oz}$ & $\mathrm{g}$ & 0.0353 \\
0.9464 & $\mathrm{qt}$ & $\mathrm{L}$ & 1.0567 \\
$\left({ }^{\circ} \mathrm{F}-32\right) \div 1.8$ & ${ }^{\circ} \mathrm{F}$ & ${ }^{\circ} \mathrm{C}$ & $\left(1.8 \times{ }^{\circ} \mathrm{C}\right)+32$
\end{tabular}




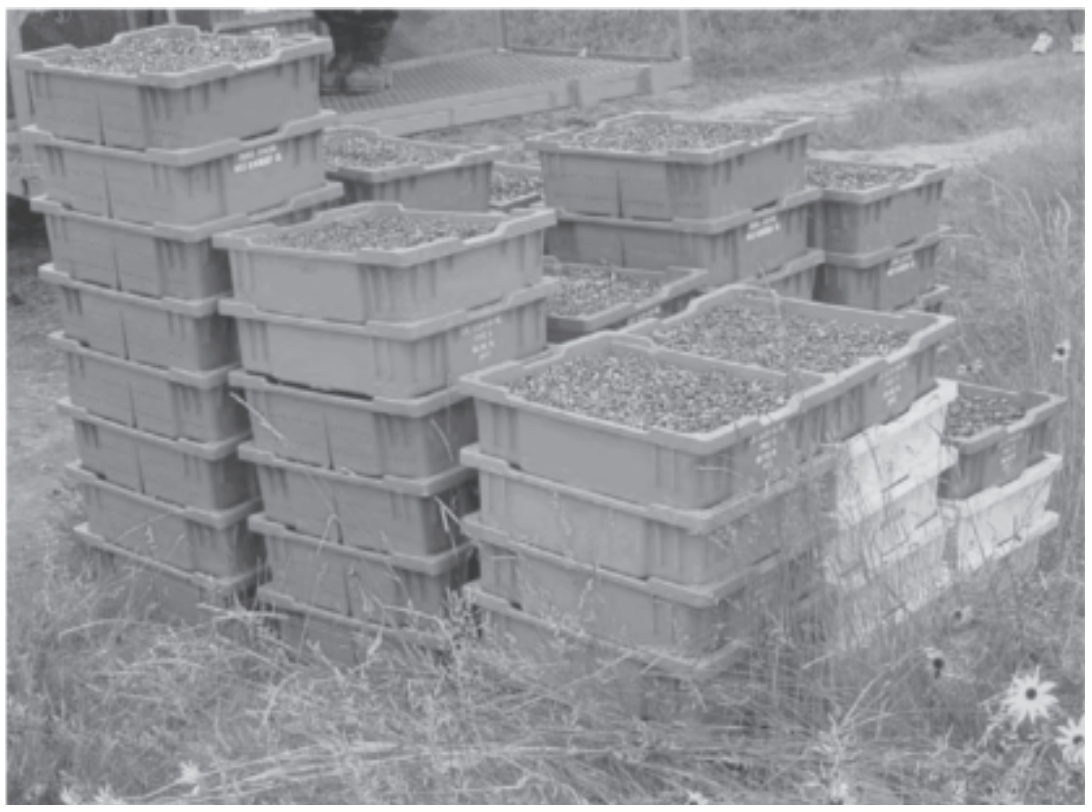

Fig. 1. Standard $20-1 \mathrm{~b}(9.1 \mathrm{~kg})$ plastic field containers used to harvest and transport wild blueberries to processing facilities. Picture courtesy of D. Percival, Nova Scotia Agricultural College.

in Nova Scotia, Prince Edward Island, New Brunswick, Maine, and Quebec, respectively (Yarborough, 2004). Recently, new mechanical harvesters with even higher capacity have been developed in Nova Scotia and Prince Edward Island.

With the increased capacity of the new mechanical harvesters, the relatively small size of the standard $20-\mathrm{lb}$ plastic container has become a limiting factor for the efficient harvesting and handling of wild blueberry fruit. For example, the larger mechanical harvesters can fill a standard container in a matter of seconds. Large numbers of these standard containers and much hand labor is required to handle production, transport, and unloading at the processing facility. The use of higher capacity containers could improve the efficiency of fruit harvesting and handling by reducing hand labor needed to collect fruit from the harvesters, stack containers for transport to processors, and unload fruit onto the processing line. The development of a high capacity container requires that fruit quality is preserved and any damage due to increased capacity is minimized or avoided. The objective of this study was to examine the design of a new, high capacity blueberry container in relation to its impact on fruit quality during harvesting, transporting, holding, and processing.

\section{Materials and methods}

In order to determine the effect of increasing the size of blueberry containers on fruit quality, experiments were conducted over four harvest seasons. In the 2001 season the effects of fruit depth on quality during transportation and holding were determined; in the 2002 season prototype pallet-sized containers were developed, and fruit quality following harvest, transport, and holding was determined; in the 2003 season the effects of dumping fruit from large-capacity containers on fruit crushing were determined; and in the 2004 season fruit crushing that occurred during harvesting, transporting, and dumping fruit from the new large capacity containers was compared with that from standard 20 -lb plastic field containers.

\section{1 season}

FrUit HARVESTING AND TRANSPORT. Three commercial fields were harvested in 2001 by commercial harvest crews using a Bragg mechanical harvester (Doug Bragg Enterprises Ltd., Collingwood, N.S.) on 21 Aug. (Rogers field, Debert, N.S.), 22 Aug. (Patterson field, Kemptown, N.S.), and 29 Aug. (Tower field, Mount Thom, N.S.). Harvested fruit were placed directly into $240 \mathrm{~L} \times 240 \mathrm{~W} \times$ $180 \mathrm{D} \mathrm{mm}$ (small) and $240 \mathrm{~L} \times 240$
$\mathrm{W} \times 360 \mathrm{D} \mathrm{mm}$ (large) white plastic buckets (Ropak Can-Am Ltd., Springhill, N.S.) by placing buckets under the collection belts of the mechanical harvester and filling each bucket to within $20 \mathrm{~mm}$ of the top. The small bucket compares to the 5 -inch depth of the standard commercial container currently used. The filled buckets were then transported by car to the Nova Scotia Agricultural College (NSAC), Truro, within 1 h of harvest, where they were labeled, covered with cloth, and held overnight at room temperature. Fruit were then transported for about $2 \mathrm{~h}$ in the trunk of a car to the Atlantic Food and Horticulture Research Centre (AFHRC), Kentville, N.S., for quality analysis. The temperature during transport ranged from 14 to 18 ${ }^{\circ} \mathrm{C}$. Fruit were sampled and assessed $\sim 24 \mathrm{~h}$ following harvest.

Fruit SAMPLing. To allow fruit sampling from the buckets, sampling ports on the side of each bucket were created by cutting out $120 \times 30 \mathrm{~mm}$ rectangular strips at the bottom (depth of $180 \mathrm{~mm}$ ) of the small buckets and at the center $(180 \mathrm{~mm})$ and bottom $(360 \mathrm{~mm})$ of the large buckets prior to filling. Duct tape was used to secure the sample ports in place prior to fruit sampling. This allowed sampling of fruit from these depths without disturbing fruit at other levels. Samples of about 50 fruit from the top of each bucket and from each sampling port were carefully taken after the fruit arrived at AFHRC.

Fruit QUality assessment. Sampled fruit were weighed and fruit quality was assessed by sorting samples into good fruit (not considered bad or trash), bad fruit (soft and crushed), and trash (unripe fruit, leaves, and twigs). Each group was weighed, and weights were compared to the original total weight to determine the portion of good fruit, bad fruit, and trash. Fruit samples of 25 randomly selected good fruit from each sample were analyzed for firmness using a Firm Tech I firmness testing instrument (BioWorks, Stillwater, Okla.) at room temperature. The fruit were placed into individual wells on a metal turntable. A $15-\mathrm{mm}$ diameter plunger compressed each individual fruit at a rate of $10 \mathrm{~mm} \cdot \mathrm{s}^{-1}$ to a threshold force of $1.47 \mathrm{~N}$. The firmness of each berry was measured by the instrument in $\mathrm{N}$ per millimeter of deformation and the average firmness of the 25 berries was recorded. 
EXPerimental Design. The experiment was a completely randomized block design with the three fields as blocks. For each field, four small buckets (two depths) and four large buckets (three depths) were filled, sampled at each depth, and fruit quality analyzed. Quality data were analyzed using analysis of variance (ANOVA) and means were separated by Tukey's test at $P \leq$ 0.05 (Jandel Corp., 1995).

\section{2 season}

Fruit HARVESTING AND TRANSPORT. Samples from four fields were assessed during the harvest season in 2002. All harvests were from the Mount Stewart area in Prince Edward Island. Samples were obtained on 26 Aug., 28 Aug., 3 Sept., and 10 Sept. 2002 , and were transported to Oxford, N.S., by refrigerated commercial transfer trucks. Containers that were $48 \mathrm{~L} \times$ $40 \mathrm{~W}$ inches in size were constructed of aluminum, and were either 6,8 , or 10 inches deep (Fig. 2). Each container was constructed so that there were four compartments on one side that were each $20 \mathrm{~L} \times 12 \mathrm{~W}$ inches, and six compartments on the other side that were each $16 \mathrm{~L} \times 10 \mathrm{~W}$ inches. Four of the compartments were equipped with hatches in the bottom-center that allowed fruit to be removed. Hatches were located in two small compartments in the center of the container, and two large compartments at the outer edges of the container (Fig. 2). Two containers were constructed for each of the three depths assessed in the study.

Fruit were harvested by mechanical harvester into standard harvest containers, and then transferred into the special containers constructed for this study. All 10 compartments of each container were filled with fruit. The containers were then transported to Oxford, N.S., a distance of about 120 miles, by truck. The containers were unloaded from the trucks and held overnight under ambient conditions at the Oxford Frozen Foods blueberry receiving facility.

Fruit SAMPLING. Fruit samples were taken at the commercial receiving facility 18 to $24 \mathrm{~h}$ after harvest from the top of the four designated compartments and from the bottom of the compartments through the sampling hatches. Fruit from each container were sampled from the same locations. Samples were placed

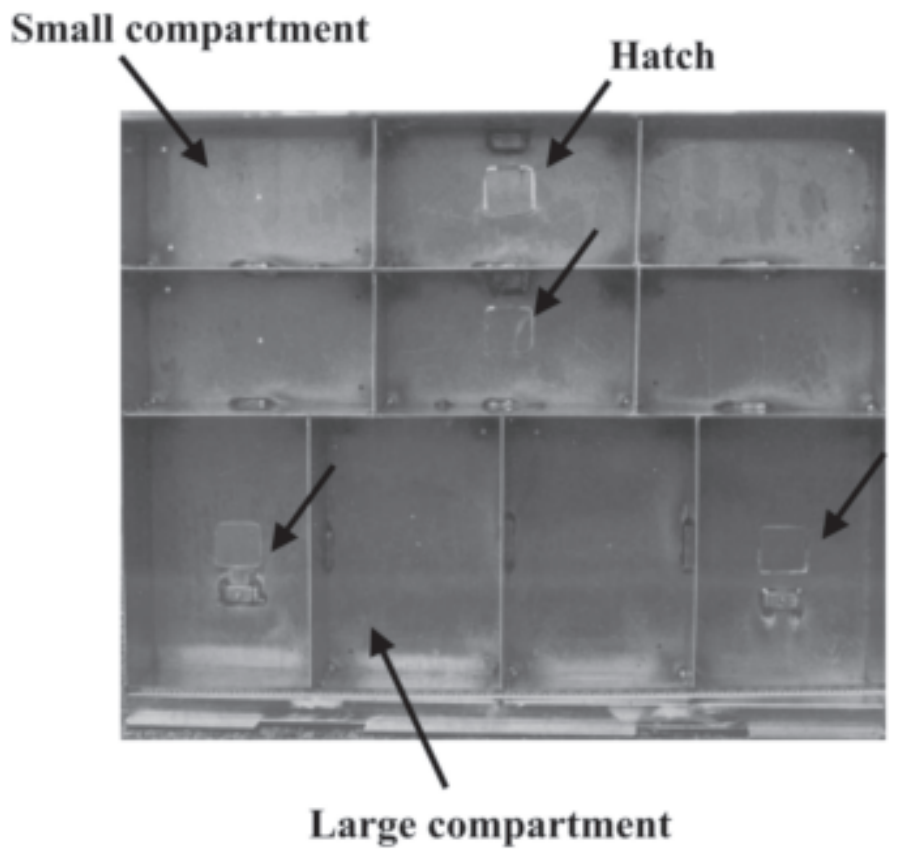

Fig. 2. Top view of aluminum container used for $\mathbf{2 0 0 2}$ fruit quality study showing two chamber sizes and hatches used for sampling fruit from the bottom of the container.

in $150-\mathrm{mL}$ polypropylene specimen containers and transported by car 50 miles to the NSAC where fruit quality was immediately assessed.

Fruit Quality assessment. After weighing the contents of each container, fruit quality was assessed as described above for the 2001 season.

Experimental DESign. The experimental design was a split-split plot with the containers (three depths) as the main plot, the four fields (harvest dates) as the sub plots, and the two sample locations (top and bottom) as the sub-sub plots. From each field, two containers of each depth were filled and fruit from the top and bottom of four compartments from each container were sampled. Data were analyzed using ANOVA, and means were separated by Tukey's test at $P \leq 0.05$ (Genstat 5 Committee, 1993).

\section{3 season}

FRUIT HARVESTING AND TRANSPORT. Blueberry fruit were harvested from fields in the Mount Stewart area in Prince Edward Island between 2 and 5 Sept. Blueberries were harvested directly into $48 \mathrm{~L} \times 45 \mathrm{~W} \times 12 \mathrm{D}$ inch MacroBin 12 containers without compartments (MacroPlastics, Fairfield, Calif.), which were filled to a depth of about 10 inches and transported to $\mathrm{Ox}^{-}$ ford, N.S., by refrigerated commercial transfer trucks. Each truck transported up to 120 containers, which were arranged in stacks of five.

FrUIT SAMPLING. Approximately 500 -g samples were taken randomly from one container in each stack of five as the containers were dumped (Fig. 3), with total numbers sampled determined by the number of containers delivered to the processing facility. Thus, 43, 22, 21 , and 22 boxes were sampled on $2,3,4$, and 5 Sept., respectively, for a total of 108 samples. To sample the individual containers, each container was tilted and held until the first large amount of fruit poured onto a processing belt. It then was tilted further to remove the remaining fruit. A sample (Top) was collected from the initial fruit on the belt by filling l-L containers with fruit as it dropped off the belt. A second sample (Bottom) was taken in the same manner from the last fruit to be poured onto the belt, which were from the bottom of the container where the compression force that occurred during dumping was assumed to be greatest. Each sample was labeled with the lot and stack numbers. Samples were obtained by Oxford Frozen Foods plant workers during the dumping process, usually between 2000 and $0700 \mathrm{HR}$, and were analyzed for crushed fruit on the same day.

Fruit Quality Analysis. Samples 


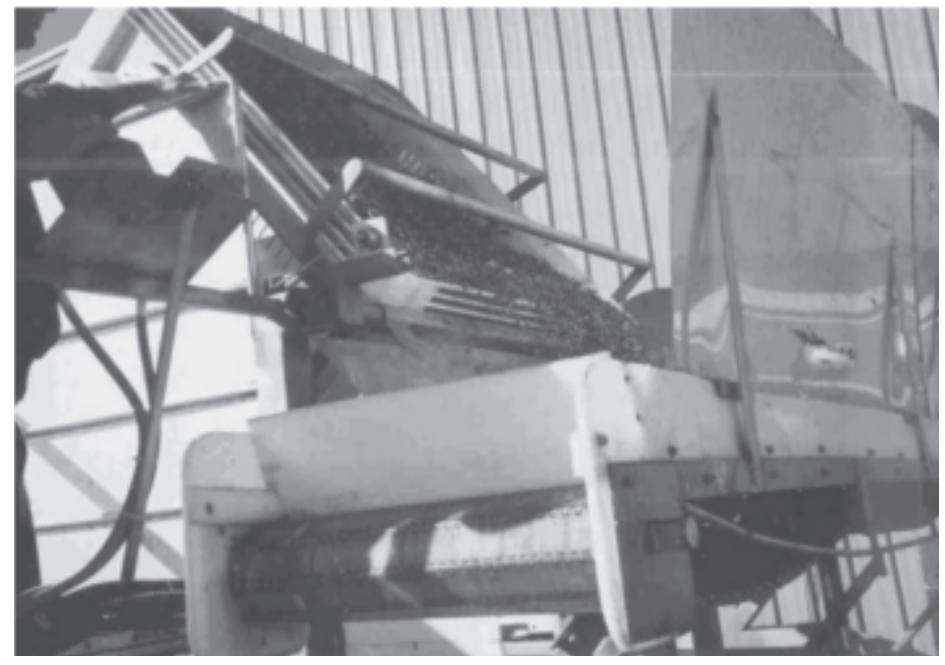

Fig. 3. Dumping of large MacroBin 12 container of wild blueberries onto a processing line conveyer belt.

that were $>500$ g were reduced to $500 \pm$ $5 \mathrm{~g}$. The samples were spread onto large white trays $(20 \times 20$ inches $)$ and carefully sorted into categories as described above for the 2001 season. From the bad fruit, only significantly damaged fruit were considered crushed; mummy berries and dried fruit were considered trash. The crushed fruit for each sample were weighed and percent crushed fruit was determined based on the initial weight of the sample. Differences between the percent crushed fruit from the top and bottom samples were analyzed using a pair-wise $t$ test (Jandel Corp., 1995).

\section{4 season}

Fruit SAMPLING. To compare the standard $18 \mathrm{~L} \times 15 \mathrm{~W} \times 5 \mathrm{D}$-inch plastic field container with the large $48 \mathrm{~L} \times$ $45 \mathrm{~W} \times 12 \mathrm{D}$-inch pallet-sized containers, fruit samples were obtained from containers following dumping on the processing line. Because of the limited availability of the prototype large-capacity harvester, large containers of fruit could not be collected at the same time as the standard field containers. Therefore, from 26 Aug. through 3 Sept., eight lots of fruit harvested in standard containers and transported by refrigerated commercial transport truck were sampled at the processing plant in Oxford, N.S. Each lot came from a different field in Nova Scotia, Prince Edward Island, or Maine and were harvested and transported in standard 20-lb plastic field containers. Fruit from the containers were dumped onto a conveyer belt and samples were two containers were compared using means and standard errors.
${ }^{2}$ Percentage by weight of undamaged fruit in the total sample. (trash).

${ }^{x} 1 \mathrm{~N} \cdot \mathrm{mm}^{-1}=5.7101 \mathrm{lbf} /$ inch.

\section{Results and discussion}

In the 2001 harvest season, there were less good fruit sampled from the 14.2-inch $(360 \mathrm{~mm})$ depth compared with the 0- (top) and 7.1-inch (180 $\mathrm{mm}$ ) depths (Table 1). Similarly, the percentage of bad fruit sampled from the 14.2-inch depth was greater than that from the 0 - and 7-inch depths. In addition to the good and bad fruit, a small amount $(<4 \%)$ of trash was in each sample. Firmness of good fruit was not significantly affected by storage depth (Table 1 ). The reduction in number of good fruit in the bottom of the large buckets indicated that fruit depths of 14.2 inches caused significant fruit damage. No difference in the number of damaged fruit was observed at the 7.1 -inch depth compared with the top.

To further test the effects of depth on fruit damage, prototype pallet-sized containers with depths of 6,8 , and 10 inches were tested under commercial handling conditions in the 2002 season. There were no differences in the percentages of good or bad fruit among the samples taken from the top or bottom of any of the three depths (Table $2)$. In addition, no differences were seen in fruit firmness. These results indicated that a container depth of 10 inches would be acceptable under the conditions evaluated and would double the depth of the currently used container.

In other studies using bulk containers, greater depth of fruit in the containers resulted in increased bruising and damage to tomatoes (Lycopersicon esculentum), apricots (Prunus armeniaca), and peaches (Prunus persica) as a result of increased compression of the fruit (Geyer et al., 2003; O'Brien et al., 1963). Vibration and shaking actions that occur during transporta-

Table 1. Quality assessment of fruit samples from three commercial blueberry fields in 2001. Fruit were harvested into containers that were $180 \mathrm{~mm}(7.1$ inches) or $360 \mathrm{~mm}$ (14.2 inches) deep and held for about $24 \mathrm{~h}$. Values are means for fruit sampled from $0-\mathrm{mm}$ (top), 180-mm, and 360-mm depths.

\begin{tabular}{lcccc}
\hline Depth & n & Good fruit $(\%)^{\mathrm{z}}$ & Bad fruit $(\%)^{\mathrm{y}}$ & $\begin{array}{c}\text { Firmness } \\
\left(\mathbf{N} \cdot \mathbf{m m}^{-1}\right)^{\mathbf{x}}\end{array}$ \\
\hline $0 \mathrm{~mm}($ Top) & 24 & $83.6 \mathrm{a}^{\mathrm{w}}$ & $14.1 \mathrm{~b}$ & $1.04 \mathrm{a}$ \\
7.1 inches $(180 \mathrm{~mm})$ & 24 & $84.6 \mathrm{a}$ & $13.2 \mathrm{~b}$ & $1.05 \mathrm{a}$ \\
14.2 inches $(360 \mathrm{~mm})$ & 12 & $74.2 \mathrm{~b}$ & $22.0 \mathrm{a}$ & $0.98 \mathrm{a}$ \\
\hline
\end{tabular}

yercentage by weight of soft and crushed fruit in the total sample, not including unripe fruit, leaves, or twigs

wMeans in each column were separated by Tukey's test with $P \leq 0.05$. 
Table 2. Quality assessment of fruit samples taken from four fields in 2002 and placed in pallet-size containers with different depths. Fruit were sampled from the top and bottom of containers after 18 to $24 \mathrm{~h}$ and evaluated for quality. Values are means of 32 samples.

\begin{tabular}{llccc}
\hline $\begin{array}{l}\text { Depth of } \\
\text { container }\end{array}$ & Location & $\begin{array}{c}\text { Good fruit } \\
(\%)^{\mathrm{z}}\end{array}$ & $\begin{array}{c}\text { Bad fruit } \\
(\%)^{\mathrm{y}}\end{array}$ & $\begin{array}{c}\text { Firmness } \\
\left(\mathbf{N} \cdot \mathbf{m m}^{-1}\right)^{\mathbf{x}}\end{array}$ \\
\hline 6 inches $(152 \mathrm{~mm})$ & Top & 70.0 & 26.3 & 0.97 \\
& Bottom & 70.5 & 28.2 & 1.00 \\
8 inches $(203 \mathrm{~mm})$ & Top & 64.3 & 31.9 & 1.02 \\
& Bottom & 62.3 & 32.2 & 1.02 \\
10 inches $(254 \mathrm{~mm})$ & Top & 63.0 & 33.7 & 1.00 \\
& Bottom & 64.1 & 31.7 & 1.01 \\
Level of significance & & & & \\
Depth of container $(\mathrm{D})$ & & 0.299 & 0.303 & 0.604 \\
Location $(\mathrm{L})$ & & 0.991 & 0.951 & 0.138 \\
D $\times \mathrm{L}$ & & 0.521 & 0.428 & 0.452 \\
\hline
\end{tabular}

${ }^{2}$ Percentage by weight of undamaged fruit in the total sample.

Percentage by weight of soft and crushed fruit in the total sample, not including unripe fruit, leaves, or twigs (trash).

${ }^{x} 1 \mathrm{~N} \cdot \mathrm{mm}^{-1}=5.7101 \mathrm{lbf} /$ inch tion can compact bulk-packaged fruit, causing additional compression as was seen in the transportation of kiwifruit (Actinidia deliciosa) (Lallu et al., 1999). Damage caused by compression is increased when fruit are subjected to dropping and impact bruising prior to filling and transporting containers (Geyer et al., 2003).

In the 2003 season results, effects of dumping wild blueberry fruit from pallet-size, large containers containing a 10 -inch depth of fruit on crushing damage were determined under commercial conditions. The mean values indicate that the damage in the bottom was consistently greater than that in the top of the containers, but differences generally were $<1 \%$ (Table 3 ). Differences in fruit crushing between samples from the top and bottom of containers was only significant for the 5 Sept. fruit. Overall, the average values of crushed berries from the top and bottom of the 108 containers sampled

Table 3. Percent crushed fruit from the top and bottom of large [ 48 inches long $\times 45$ inches wide $\times 12$ inches deep $(121.9 \times 114.3 \times 30.5 \mathrm{~cm})]$ pallet-size containers following harvesting and transporting to commercial processing facility in 2003.

\begin{tabular}{lcccc}
\hline Harvest & & \multicolumn{3}{c}{ Crushed fruit (\%) } \\
\cline { 3 - 4 } date & $\mathbf{n}$ & Top & Bottom & $\boldsymbol{P}^{\mathbf{z}}$ \\
\hline 2 Sept. & 43 & 2.41 & 2.53 & 0.489 \\
3 Sept. & 22 & 2.95 & 3.36 & 0.100 \\
4 Sept. & 21 & 2.28 & 2.50 & 0.283 \\
5 Sept. & 22 & 3.18 & 4.22 & 0.001 \\
All dates & 108 & 2.65 & 3.04 & 0.001 \\
\hline
\end{tabular}

${ }^{2}$ Probabilities based on a paired $t$ test. were $2.65 \%$ and $3.04 \%$, respectively. This small difference indicates that the filling depth of 10 inches did not cause excessive damage to fruit on the bottom from compression or crushing during dumping.

Damage inflicted during transportation and handling is dependent on the initial quality of the fruit, and damage may increase as fruit become more ripe and are less able to withstand physical abuse. Differences in fruit damage observed between different harvest dates/fields may reflect differences in initial quality (Table 3 ). Following the physical abuse that occurs during winnowing of wild blueberries, late harvested fruit were softer and developed more anthocyanin leakage than less mature early harvested fruit (Donahue et al., 1999). When highbush blueberry (Vaccinium corymbosum) fruit were shipped from Chile to North
America, 'Bluecrop' fruit, which were firmer than 'Ivanhoe' fruit, had less bruising, and maintained better quality following transport (Beaudry et al., 1998). Greater ripeness of other fruit, including avocados (Persea americana), tomatoes, and peaches, resulted in more bruising and damage as a result of impaction, vibration, compaction, and simulated transport when compared with less-ripe fruit (Arpaia et al., 1987; Olorunda and Tung, 1985; Vergano et al., 1991).

There was little difference in the rate of fruit crushing when comparing standard 20 -lb plastic containers with large containers (Table 4). In fact, fruit from the top of the large containers had substantially less crushing than those samples from the standard containers. Fruit from the bottom of the large containers had a similar rate of crushing as the standard container.

The amounts of fruit damage varied extensively among the eight lots handled in standard containers. Average damage ranged from a low of $4.84 \%$ to a high of $12.26 \%$. These differences may reflect the differences in initial fruit quality, harvest methods, postharvest handling, transportation distance, and/or delays prior to processing. While the samples taken from the large containers represent fewer fields and handling variables, the similar rates of crushing when compared to the standard containers and the previous seasons' results all suggest that the large containers are a viable replacement for the standard containers.

The large containers used in the 2003 and 2004 seasons had a volume of about $15 \mathrm{ft}^{3}$. Since they were filled about 10 inches deep, they held about
Table 4. Percent crushed fruit following harvesting and transporting in standard $20-1 \mathrm{~b}(9.1 \mathrm{~kg})$ plastic containers [18 inches long $\times 15$ inches wide $\times 5$ inches deep $(457 \times 381 \times 127 \mathrm{~mm})]$ compared with large 320-1b $(145.1 \mathrm{~kg})$ containers $[48$ inches long $\times 45$ inches wide $\times 12$ inches deep $(121.9 \times 114.3 \times 30.5 \mathrm{~cm})]$ in 2004 . Fruit were sampled from 172 standard containers representing eight lots of fruit received at a commercial processing facility. The 16 large containers represent fruit received at a commercial processing facility over $2 \mathrm{~d}$ and were sampled from the top and bottom of the large containers.

\begin{tabular}{lrcc}
\hline Container & N & $\begin{array}{c}\text { Crushed } \\
\text { fruit (\%) }\end{array}$ & SE \\
\hline Standard 20-lb & & & \\
plastic container & 172 & 7.59 & 0.61 \\
$\quad$ Minimum & 24 & 4.84 & 0.68 \\
$\quad$ Maximum & 18 & 12.26 & 1.98 \\
Large container (top) & 16 & 4.85 & 0.89 \\
Large container (bottom) & 16 & 8.07 & 1.18 \\
\hline
\end{tabular}


$12.5 \mathrm{ft}^{3}$ of fruit weighing about 320 lb. This is about 16 times more fruit than is held in the standard containers currently used. Therefore, adapting harvest and handling procedures to use these larger containers would significantly reduce time and labor requirements.

We conclude that the size of containers for handling wild blueberries could be increased to the pallet-size containers holding a fruit depth of 10 inches without causing additional damage to fresh fruit during harvest and transport. Damage caused to fruit by the dumping of the large pallet-size containers was minimal and therefore the use of large containers appears promising to increase harvest and handling efficiency. In addition, the use of large containers may be beneficial to berry quality if improved efficiency enables harvesting at optimum harvest dates, reduces handling, and results in shorter holding periods. Further work in the design of the container should include features that facilitate air flow in the fruit as temperature is also a critical parameter for maintaining berry quality during transport (Sanford et al., 1991).

\section{Literature cited}

Arpaia, M.L., F.G. Mitchell, P.M. Katz, and G. Mayer. 1987. Susceptibility of avocado fruit to mechanical damage as influenced by variety, maturity and stage of ripeness. South African Avocado Growers' Assn. 10:149-151
Beaudry, R.M., C.E. Moggia, J.B. Retamales, and J.F. Hancock. 1998. Quality of 'Ivanhoe' and 'Bluecrop' blueberry fruit transported by air and sea from Chile to North America. HortScience 33:313317 .

Donahue, D.W., A.A. Bushway, K.E. Moore, and B.J. Lagasse. 1999. Maine wild blueberries field winnowing systems. Tech Bul. Maine Agr. For. Expt. Sta. 174.

Genstat 5 Committee. 1993. Genstat 5 Release 3 reference manual. Clarendon Press, Oxford, U.K.

Geyer, M., B. Herold, B. Oberbarnscheidt, B. Borsa, L. Kovacs, and F. Jakovac. 2003. Detection of mechanical load and damage of industrial tomatoes during transport. Acta Hort. 599:273-280.

Jackson, E.D., K.A. Sanford, R.A. Lawrence, K.B. McRae, and R. Stark. 1999. Lowbush blueberry quality changes in response to prepacking delays and holding temperatures. Postharvest Biol. Technol. 15:117-126.

Jandel Corp. 1995. SigmaStat 7. Statistical software user's manual. Jandel Corp., San Rafael, Calif.

Kinsman, G. 1986. The history of the lowbush blueberry industry in Nova Scotia 1880-1950. Blueberry Producers' Assn. of Nova Scotia, 13 June 2005. <http:// www.nsac.ns.ca/wildblue/hist/kinsmanl880>.

Kinsman, G. 1993. The history of the lowbush blueberry industry in Nova Scotia 1950-1990. Blueberry Producers' Assn. of Nova Scotia, 13 June 2005. <http:// www.nsac.ns.ca/wildblue/hist/kinsman5090>.
Lallu, N., K. Rose, C. Wiklund, and J. Burdon. 1999. Vibration induced physical damage in packed Hayward kiwifruit. Acta Hort. 498:307-312.

O’Brien, M., L.L. Claypool, S.J. Leonard, G.K. York, and J.H. MacGillivray. 1963. Causes of fruit bruising on transport trucks. Hilgardia 35(6):113-124.

Olorunda, A.O. and M.A. Tung. 1985. Simulated transit studies on tomatoes; effects of compressive load, container, vibration and maturity on mechanical damage. J. Food Technol. 20:669-678.

Peterson, D.L. 1992. Harvest mechanization for deciduous tree fruits and brambles. HortTechnology 2:85-88.

Sanford, K.A., P.D. Lidster, K.B. McRae, E.D. Jackson, R.A. Lawrence, R. Stark, and R.K. Prange. 1991. Lowbush blueberry quality changes in response to mechanical damage and storage temperature. J. Amer. Soc. Hort. Sci. 116:47-51.

Vergano, P.J., R.F. Testin, and W.C. Newall, Jr. 1991. Peach bruising: Susceptibility to impact, vibration, and compression abuse. Trans. Amer. Soc. Agr. Eng. 34:2110-2116.

Yarborough, D. 2004. Factors contributing to the increase in productivity in the wild blueberry industry, p. 33-44. In: C.F. Forney and L.J. Eaton (eds.). Proc. Ninth North Amer. Blueberry Res. and Ext. Workers Conf. Food Products Press, New York.

Yarborough, D. 2005. Wild blueberry crop statistics (from 1924 to present). Univ. of Maine Coop. Ext., Orono. 13 June 2005. $<$ http://wildblueberries.maine.edu/FactSheets/CropStatistics.htm>. 